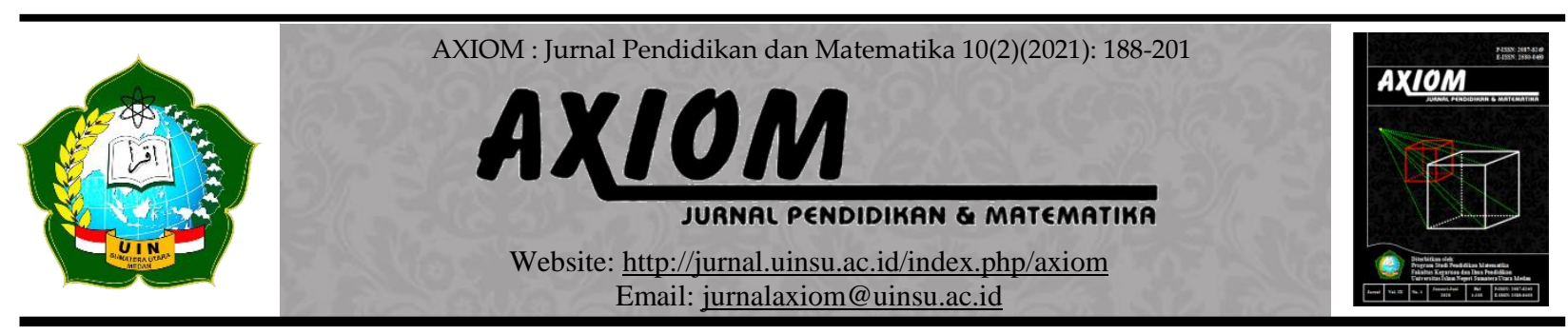

\title{
SISTEM PENDUKUNG KEPUTUSAN PENERIMAAN BEASISWA BIDIKMISI DI UINSA DENGAN MENGGUNAKAN ANALYTICAL HIERARCHY PROCESS (AHP)
}

\author{
Oleh:
}

\author{
Mila Iflakhah ${ }^{1}$, Moh. Hafiyusholeh ${ }^{2}$ \\ ${ }^{1,2}$ Matematika, Sains dan Teknologi, UIN Sunan Ampel Surabaya \\ E-mail: ${ }^{1}$ milaiflakhah09@ gmail.com, ${ }^{2}$ hafiyusholeh@uinsby.ac.id
}

doi : 10.30821/axiom.v10i2.8837

\begin{abstract}
Abstrak:
Beasiswa merupakan pemberian bantuan biaya pendidikan kepada mahasiswa yang mampu dalam bidang akademik tetapi tidak dalam perekonomian. Namun masih sering terjadi kendala dalam pemrosesan seleksi pendaftar beasiswa, yaitu banyaknya kriteria yang harus diperhatikan dan banyaknya data pendaftar sehingga pengambilan keputusan menjadi relatif lebih sulit. Tujuan dari penelitian ini adalah memberikan alternatif dalam pengambilan keputusan penerima bantuan beasiswa untuk mahasiswa fakultas sains dan teknologi UINSA dengan menggunakan metode Analytical Hierarchy Process (AHP). Data yang diolah adalah data primer yang diperoleh dari angket. Data yang telah terkumpul selanjutnya dianalisis dengan matriks perbandingan berpasangan untuk menentukan nilai eigen dan vektor eigen. Hasil penelitian menunjukkan bahwa dari 39 pendaftar diperoleh 12 pendaftar yang menjadi prioritas dalam mendapatkan beasiswa Bidikmisi. Berturut-turut mahasiswa dengan kode Z1, Z2, Z5, Z7, Z10, Z19, Z20, Z21, Z23, Z29, Z32, Z35 dengan masing-masing bobot sebesar $0.34 \%, 0.27 \%, 0.27 \%, 0.28 \%, 0.36 \%$, $0.33 \%, 0.29 \%, 0.31 \%, 0.34 \%, 0.29 \%, 0.27 \%, 0.35 \%$.
\end{abstract}

Kata Kunci:

Vektor Eigen, Analytical Hierarchy Process (AHP), Nilai Eigen

\section{Abstract:}

The scholarship is the provision of tuition assistance to students who are capable of academics but have difficulties economically. However, some obstacles are often found throughout the screening process of scholarship applicants, such as the number of criteria to fulfill and the number of registrant data that results in difficulties in making a decision. This study aims to provide an alternative in decision making on the screening process of scholarship applicants for students from the Faculty of Science and Technology at the Universitas Islam Negeri Sunan Ampel by using the Analytical Hierarchy Process (AHP). The data processed are from the primary data obtained from questionnaires. The data obtained were analyzed by using a pairwise comparison matrix to determine the eigenvalues and eigenvectors. The results indicate that of 39 registrants, 12 of them became a priority in getting the Bidikmisi scholarship. Consecutively, students with codes Z1, Z2, Z5, Z7, Z10, Z19, Z20, Z21, Z23, Z29, Z32, Z35 have the score of $0.34 \%, 0.27 \%, 0.27 \%, 0.28 \%, 0.36 \%, 0.33 \%, 0.29 \%, 0.31 \%, 0.34 \%, 0.29 \%, 0.27 \%, 0.35 \%$.

\section{Keywords:}

Eigenvector, Analytical Hierarchy Process (AHP), Eigenvalue 


\section{A. Pendahuluan}

Perguruan tinggi merupakan wadah untuk memperoleh pengetahuan atau wawasan yang diinginkan sesuai dengan kemampuannya. Setiap lembaga pendidikan baik negeri maupun swasta menyediakan bantuan melalui program beasiswa dalam rangka untuk memfasilitasi mahasiswa yang memiliki masalah dengan perekonomian tetapi memiliki kemampuan dalam prestasi, ataupun memiliki kompetensi tertentu. Pada perguruan tinggi negeri Universitas Islam Negeri Sunan Ampel Surabaya menyediakan banyak beasiswa antara lain beasiswa Bidikmisi, beasiswa unggulan, beasiswa Bank Indonesia (BI), beasiswa tahfidz, beasiswa supersemar, beasiswa mahasiswa miskin, dan lain sebagainya (Rizal, 2013).

Salah satu beasiswa yang diminati oleh mahasiswa yaitu beasiswa Bidikmisi karena beasiswa tersebut memberikan bantuan berupa pembiayaan pendidikan di perguruan tinggi negeri maupun swasta dari pemerintah yang mempunyai kemampuan dalam bidang akademik akan tetapi ketidakmampuan dalam perekonomian (Kirom, Kadier, \& Bilfaqih, 2012). Putra \& Hardiyanti (2011) menyatakan bahwa dalam beasiswa biasanya terdapat kriteria-kriteria yang ditetapkan, misalnya pekerjaan orang tua, rumah tinggal keluarga, ekonomi, pendidikan dan masih banyak kriteria-kriteria yang lainnya. Semakin banyaknya kriteria yang ditetapkan, maka akan berdampak, pada sulitnya pengambilan keputusan. Hal ini sangat memungkinkan unsur subjektifitas banyak mempengaruhi keputusan, oleh karenanya dibutuhkan suatu metode yang dapat membantu pengambil keputusan untuk membuat suatu keputusan secara objektif dengan tetap memperhatikan banyak kriteria. Metode yang dimaksud diantaranya adalah sistem pendukung keputusan.

Sistem Pendukung Keputusan (SPK) merupakan metode tersebut dapat membantu dalam peningkatan kualitas keputusan dengan membentuk proses dari pengambilan keputusan yang akurat, logis, dan praktis (Magdalena, 2012). Ishak (2016) mengemukakan beberapa sistem yang dapat digunakan dalam membantu pemrosesan pengambilan keputusan yaitu Simple Additive Weighting (SAW), Weigh Product (WP), Tecnique For Order Preference by Similarity to Ideal Solution (TOPSIS), Analytical Hierarchy Process (AHP), Preference Ranking Organization Method for Enrichment Evaluation (PROMETHEE), dan Elimination and Choise Translation Reality (ELECTRE).

Metode AHP merupakan suatu teknik pengambilan keputusan berdasarkan beberapa kriteria (multikriteria) dilakukan dengan cara menentukan prioritas atau pembobotan dari masing-masing alternatif yang tersedia (Darmanto, Latifah, \& Susanti, 2014). Hafiyusholeh et al. (2015) mengungkapkan bahwa terdapat pendekatan Analytical Hierarchy Process (AHP) untuk mendapatkan vektor prioritas, yaitu Eigenvalue Method (EM), Chi Square Method $\left(x^{2} m\right)$, Last Square Method (LSM), Singular Value Decomposition (SVD) dan lain sebagainya.

Beberapa penelitian yang berkaitan dengan AHP menurut Kirom (2011) mengungkapkan bahwa pengambilan keputusan menggunakan metode Analytical Hierarchy Process dapat mempermudah pemrosesan penerimaan beasiswa di ITS, kemudian oleh Hafiyusholeh et al. (2015) yang menyimpulkan bahwa AHP merupakan sistem pendukung keputusan berbasis multikriteria dengan nilai eigen maksimum lebih dari atau sama dengan $n$, lalu penelitian yang dilakukan oleh Astuti et al. (2011) mengkaji mengenai AHP dalam membantu calon mahasiswa dalam memilih perguruan tinggi komputer swasta. Selanjutnya dilakukan oleh Setiawan et al. (2015) menghasilkan penelitiannya dalam sistem pendukung keputusan dengan menggunakan AHP dapat mempermudah memilih karyawan baru dari perhitungan pembobotan dan perangkingan yang efisien serta objektif.

Berdasarkan uraian diatas, maka penulis tertarik melakukan penelitian tentang "sistem pendukung keputusan penerimaan beasiswa Bidikmisi di UINSA dengan menggunakan Analytical Hierarchy Process (AHP). Hal ini diharapkan dapat dijadikan sebagai alternatif sistem pengambilan keputusan dalammembantu proses seleksi penerimaan beasiswa dengan menetukan nilai bobot untuksetiap kriteria dan alternatif terbaik. 


\section{B. Kajian Teoritis}

Beasiswa Bidikmisi merupakan pemberian bantuan berupa pembiayaan pendidikan di perguruan tinggi negeri maupun swasta dari pemerintah yang berkelulusan Sekolah Menengah Atas (SMA) atau sederajat yang mempunyai kemampuan dalam bidang akademik akan tetapi ketidakmampuan dalam perekonomian. Bantuan tersebut untuk memberikan akses pembelajaran di perguruan tinggi, mengembangkan prestasi, mewujudkan lulusan yang berjiwa kemandirian, berguna bagi masyarakat, dan berjiwa sosial sehingga mampu mengurangi kemiskinan dan pemberdayaan masyarakat (Takriyuddin, Mukmin, \& Yunus, 2016).

\section{Analytical Hierarchy Process (AHP)}

Magdalena (2012) mengungkapkan bahwa SPK atau Management Decision System diperkenalkan oleh Michael Stewart Scott Morton sekitar awal tahun 1970-an. Pujiarti et al. (2011) menyatakan bahwa SPK merupakan sekumpulan komponen dalam proses pemilihan keputusan yang apabila digabungkan akan saling berhubungan dan terdapat berbagai tindakan alternatif yang didasarkan pada fakta serta pendekatan sistematis sehingga didapatkan solusi terbaik dari suatu permasalahan dengan mudah dan efektif.

Saefudin \& Wahyuningsih (2017) menyatakan bahwa AHP merupakan salah satu metode pendukung keputusan yang dikembangkan pada tahun 1970 oleh Thomas Lorie Saaty di Wharton Scoll. Thomas Lorie Saaty adalah ahli matematikawan dari USA pada Pittsburgh University. Menurut Kenty \& Nugroho (2016) AHP merupakan suatu metode untuk mengatasi permasalahan yang tidak terstruktur dalam komponen-komponennya kemudian menyusun komponen-komponen tersebut dalam suatu hirarki. Memberikan penilaian berupa angka untuk membuat perbandingan dan menghasilkan suatu sintesa yang menetapkan nilai prioritas antar komponen-komponen tersebut. Prinsip AHP menurut Saaty (2005) yang perlu diperhatikan sebagai berikut:

a. Dekomposisi

Dekomposisi merupakan suatu pemecahan atau penjabaran permasalahan yang komplek berubah menjadi suatu elemen yang hierarki, dari elemen atau unsur-unsur tersebut saling berhubungan.

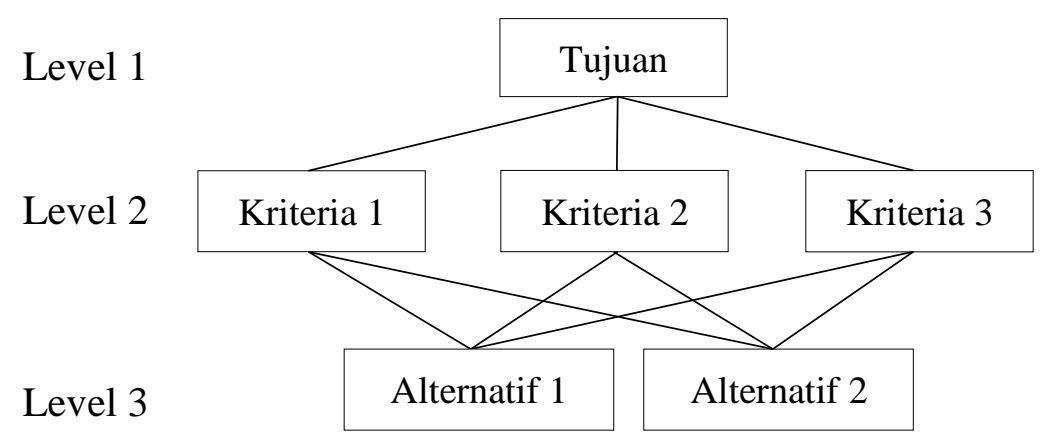

\section{Gambar 1. Struktur Hierarki}

b. Comparative Judgement

Comparative Judgement bertujuan untuk membuat penilaian tentang kepentingan relatif dari elemen baris terhadap elemen kolom. Nilai yang digunakan untuk mengisi perbandingan tersebut didapatkan dari ketetapan Saaty (2005) dengan skala pilihan 1 sampai dengan 9. 
Tabel 1. Skala Penilaian Perbandingan

\begin{tabular}{cl}
\hline Tingkat kepentingan & \multicolumn{1}{c}{ Keterangan } \\
\hline 1 & Kedua kriteria mempunyai kepentingan yang sama \\
3 & Kriteria satu sedikit lebih berpengaruh dibandingkan lainnya \\
7 & Kriteria satu jelas berpengaruh dibandingkan lainnya \\
9 & Kriteria satu sangat berpengaruh dibandingkan lainnya \\
& Kriteria satu mutlak sangat berpengaruh dibandingkan \\
& lainnya \\
Nilai tengah diantara dua kriteria \\
Resiprokal
\end{tabular}

Dalam melakukan perbandingan berpasangan diputuskan oleh beberapa para ahli dengan diperlukan rata ukur (geometric mean) dengan menggunakan persamaan:

$$
\text { Rata Ukur }=\sqrt[n]{X_{1}+X_{2}+\cdots+X_{n}}
$$

Keterangan: $n=$ Jumlah responden

$X_{1}=$ Pakar ke- 1

$X_{2}=$ Pakar ke- 2

$X_{n}=$ Pakar ke-n

c. Syntesis of priority.

Dilakukan dengan cara menganilisis prioritas elemen menggunakan skala perbandingan, perbandingan antar dua elemen sehingga semua elemen juga terpenuhi. Dalam Syntesis of Priority terdapat eigen value method untuk memperoleh bobot relatif dalam unsur-unsur pengambilan keputusan.

Adapun tahapan proses pengambilan keputusan Analytical Hierarchy Process yaitu: (a) Mengidentikasi masalah, (b) Penyusunan hierarki, (c) Penyusunan prioritas elemen, (d) Sintesis, (e) Mengukur konsistensi, dan (f) Dilakukan perulangan tahap 3, 4, dan 5 untuk semua tingkat hierarki.

\section{Eigen Value}

Cara menentukan nilai peringkat relatif kriteria serta alternatif maka diperlukan perbandingan berpasangan (pairwise comparisons) (Hafiyusholeh \& Asyhar, 2016). Bobot dan prioritas dimulai dengan mengasumsikan adanya elemen pada suatu sistem operasi dimana elemen-elemen tersebut dilambangkan $M_{1}, M_{2}, \ldots, M_{n}$. Setiap elemen matriks yang dioperasikan, didapatkan bahwa matriks positif $M_{n \times n}$ yang berbalikan (resiprokal) yaitu $m_{j i}=\frac{1}{m_{i j}}$. Lambang dari bobot setiap elemen disimbolkan dengan $w$ dan diasumsikan bobot elemen sebanyak $n$ perbandingan yaitu $w_{1}, w_{2}, \ldots, w_{n}$.

Tabel 2. Matriks Operasi Setiap Elemen

\begin{tabular}{ccccc}
\hline $\boldsymbol{M}$ & $\boldsymbol{M}_{\mathbf{1}}$ & $\boldsymbol{M}_{\mathbf{2}}$ & $\ldots$ & $\boldsymbol{M}_{\boldsymbol{n}}$ \\
\hline $\boldsymbol{M}_{\mathbf{1}}$ & $m_{11}$ & $m_{12}$ & $\ldots$ & $m_{1 n}$ \\
$\boldsymbol{M}_{\mathbf{2}}$ & $m_{21}$ & $m_{22}$ & $\ldots$ & $m_{2 n}$ \\
$\vdots$ & $\vdots$ & $\vdots$ & & $\vdots$ \\
$\boldsymbol{M}_{\boldsymbol{n}}$ & $m_{n 1}$ & $m_{n 2}$ & $\ldots$ & $m_{n n}$ \\
\hline
\end{tabular}

Suatu bentuk matriks konsisten dengan vektor $w$ sehingga elemen $m_{i j}$ dapat ditulis:

dengan $i, j=1,2, \ldots, n$

$$
m_{i j}=\frac{w_{i}}{w_{j}}
$$

Jadi, didapatkan matriks konsisten yaitu: 
Mila Iflakhah \& Moh. Hafiyusholeh: Sistem Pendukung Keputusan Penerimaan Beasiswa Bidikmisi di UINSA dengan Menggunakan Analytical Hierarchy Process (AHP)

$$
m_{i j} \cdot m_{j k}=\frac{w_{i}}{w_{j}} \cdot \frac{w_{j}}{w_{k}}=m_{i k}
$$

Dari persamaan (2), diperoleh:

$$
m_{i j}=\frac{w_{i}}{w_{j}}=\frac{1}{w_{j} / w_{i}}=\frac{1}{m_{j i}}
$$

Dari persamaan (3), sehingga:

$$
m_{i j} \cdot m_{j i}=m_{i j} \cdot \frac{w_{j}}{w_{i}}=\frac{w_{i}}{w_{j}} \cdot \frac{w_{j}}{w_{i}}=1
$$

Demikian pairwise comparison menjadi:

Jadi,

$$
\begin{aligned}
\sum_{j=1}^{n} m_{i j} \cdot w_{j} \cdot \frac{1}{w_{i}} & =\sum_{j=1}^{n} \frac{w_{i}}{w_{j}} \cdot \frac{w_{j}}{w_{i}} \\
\sum_{j=1}^{n} m_{i j} \cdot w_{j} \cdot \frac{1}{w_{i}} & =\sum_{j=1}^{n} \frac{w_{i}}{w_{i}} \\
& =\sum_{j=1}^{\sum_{i i}^{n}} m_{i i} \\
& =\underbrace{1+1+\cdots+1}_{\text {sebanyak } n} \\
& =n
\end{aligned}
$$

$$
\begin{gathered}
\sum_{j=1}^{n} m_{i j} \cdot w_{j} \cdot \frac{1}{w_{i}}=n ; i=1,2,3, \ldots, n \\
\sum_{j=1}^{n} m_{i j} \cdot w_{j}=n w_{i} ; i=1,2,3, \ldots, n
\end{gathered}
$$

Persamaan (5) dan (6), ekuivalen dengan bentuk persamaan matriks:

$$
M w=n w
$$

dimana $M$ merupakan bentuk matriks dengan $w$ melambangkan vektor eigen dan $n$ nilai eigen.

Kemudian pada aljabar linier, bahwa semua nilai eigen $\lambda_{i}=1,2, \ldots, n$ adalah nol kecuali satu yang disebut dengan $\lambda_{\text {maks }}$. Dalam bentuk persamaan matriks dapat ditulis sebagai berikut:

$$
\left[\begin{array}{cccc}
1 & \frac{w_{1}}{w_{2}} & \cdots & \frac{w_{1}}{w_{n}} \\
\frac{w_{2}}{w_{1}} & 1 & \cdots & \frac{w_{2}}{w_{n}} \\
\vdots & \vdots & \ddots & \vdots \\
\frac{w_{n}}{w_{1}} & \frac{w_{n}}{w_{2}} & \cdots & 1
\end{array}\right]\left[\begin{array}{c}
w_{1} \\
w_{2} \\
\vdots \\
w_{n}
\end{array}\right]=n\left[\begin{array}{c}
w_{1} \\
w_{2} \\
\vdots \\
w_{n}
\end{array}\right]
$$

Karena $M$ merupakan matriks positif yang resiprocal, maka $m_{j i}=\frac{1}{m_{i j}}$ dimana $i, j=$ $1,2, \ldots, n$ dan $m_{i i}=1$ untuk semua nilai $i$, berlaku:

$$
\sum_{i=1}^{n} \lambda_{i}=n
$$

Dalam kasus umum terdapat nilai-nilai $\frac{w_{i}}{w_{j}}$ yang tidak bisa diberikan secara tepat tetapi hanya bisa ditaksir, sehingga permasalahannya sekarang menjadi $M w=\lambda_{\text {maks }} w$ dimana $\lambda_{\text {maks }}$ merupakan nilai eigen yang terbesar dari $M$. Nilai $\lambda_{\text {maks }}$ yang digunakan untuk mengkontruksi nilai vektor prioritas yang lebih besar daripada ukuran matriks $M$ yang akan diuraikan dalam teorema sebagai berikut. 
Teorema 1. Misalkan $M=\left(m_{i j}\right) \in M_{n}(\mathbb{C}), M>0$. Jika $w$ merupakan vektor tak nol di $\mathbb{C}$, sehingga $M w=\lambda_{\text {maks }} w$, maka $\lambda_{\text {maks }} \geq n$ (Hafiyusholeh \& Asyhar, 2016)

\section{Bukti:}

Karena $w$ merupakan vektor eigen berkaitan dengan $\lambda_{\text {maks }}$, berlaku:

$$
\left(M-\lambda_{\text {maks }} I\right) w=0
$$

Persamaan ke- $i$ dari persamaan linier diatas dapat ditulis:

Dengan

$$
\sum_{j=1}^{n} a_{i j} \cdot w_{j}-\lambda_{m a k s} w_{i}=0
$$

Diperoleh:

$$
\begin{aligned}
\lambda_{\text {maks }}=\sum_{j=1}^{n} m_{i j} \frac{w_{j}}{w_{i}} & \lambda_{\text {maks }}=\sum_{j=1, i=1}^{n} m_{i j} \frac{w_{j}}{w_{i}}+\sum_{j=1, i \neq 1}^{n} m_{i j} \frac{w_{j}}{w_{i}} \\
& =1+\sum_{j=1, i \neq 1}^{n} m_{i j} \frac{w_{j}}{w_{i}} \\
\sum_{i=1}^{n} \lambda_{\text {maks }} & =\sum_{i=1}^{n} 1+\sum_{i=1}^{n}\left(\sum_{j=1, i \neq 1}^{n} m_{i j} \frac{w_{j}}{w_{i}}\right)
\end{aligned}
$$

$$
n \lambda_{\text {maks }}=n+\sum_{i=1}^{n} \sum_{j=1, i \neq 1}^{n} m_{i j} \frac{w_{j}}{w_{i}}
$$

Karena $m_{i j}=\frac{1}{m_{j i}}, i, j=1,2, \ldots, n$ dan $m_{j i} \frac{w_{i}}{w_{j}}=\frac{1}{m_{i j} \frac{w_{j}}{w_{i}}}$, dengan $x+\frac{1}{x}=2+\frac{(x-1)^{2}}{x}, x \neq 0, x=m_{i j} \frac{w_{j}}{w_{i}}$, maka diperoleh:

Perhatikan bahwa:

$$
\begin{aligned}
\lambda_{\text {maks }} & =1+\frac{1}{n} \sum_{i=1}^{n} \sum_{j=i+1}^{n}\left(m_{i j} \frac{w_{j}}{w_{i}}+\frac{1}{m_{i j} \frac{w_{j}}{w_{i}}}\right) \\
& =1+\frac{1}{n} \sum_{i=1}^{n} \sum_{j=i+1}^{n}\left(2+\frac{\left(m_{i j} w_{j}-w_{i}\right)^{2}}{m_{i j} w_{i} w_{j}}\right)
\end{aligned}
$$

Dengan demikian didapatkan:

$$
\begin{aligned}
\sum_{i=1}^{n} \sum_{j=i+1}^{n} 2 & =\sum_{2}^{n} 2+\sum_{3}^{n} 2+\cdots+\sum_{n}^{n} 2 \\
& =2(n-1)+2(n-2)+\cdots+2(n-(n-1)) \\
& =2[(n-1)+(n-2)+\cdots+1] \\
& =2\left[\frac{(n-1)}{2}[2(n-1)+(n-2)(-1)]\right] \\
& =2\left[\frac{(n-1) n}{2}\right] \\
& =(n-1) n
\end{aligned}
$$

$$
\lambda_{\text {maks }}=n+\sum_{i=1}^{n} \sum_{j=i+1}^{n}\left(\frac{\left(m_{i j} w_{j}-w_{i}\right)^{2}}{n m_{i j} w_{i} w_{j}}\right) \geq n
$$

Dari uaraian diatas, bisa diambil kesimpulan bahwa $\lambda_{\text {maks }} \geq n$. Dan kesamaan dalam $\lambda_{\text {maks }}=n$ hanya dipenuhi jika dan hanya jika $m_{i j} \frac{w_{i}}{w_{j}}$ untuk $i, j=1,2, \ldots, n$. Dengan kata lain, apabila $\lambda_{\text {maks }}$ dekat dengan $n$, maka $w$ akan konsiten. 
Saaty (2002) mengatakan bahwa indikator terhadap kekonsistensinan diukur dengan indeks konsisten (Consistency Index) atau yang disebut CI dengan rumus:

Keterangan:

$$
C I=\frac{\lambda_{\operatorname{maks}}-n}{n-1}
$$

$\mathrm{CI}=$ Rasio Penyimpangan (deviasi) konsistensi (Consistency Ratio)

$\lambda_{\text {maks }}=$ nilai eigen maksimum

$n \quad=$ ukuran matriks

Kemudian menghitung Rasio Konsistensi/Consistency Ratio (CR) untuk mengukur batasan terhadap ketidakkonsistenan suatu matriks dengan menggunakan rumus:

Keterangan:

$$
C R=\frac{C I}{R I}
$$

$\mathrm{CR} \quad=$ Rasio Konsisten

IR = Indeks Random

Nilai Random Index (RI) dipaparkan pada tabel sebagai berikut:

Tabel 3. Nilai Random Index (RI)

\begin{tabular}{ccccccccc}
\hline $\mathbf{n}$ & $\mathbf{1}$ & $\mathbf{2}$ & $\mathbf{3}$ & $\mathbf{4}$ & $\mathbf{5}$ & $\mathbf{6}$ & $\mathbf{7}$ & $\mathbf{8}$ \\
\hline $\mathbf{R I}$ & 0,00 & 0,00 & 0,58 & 0,90 & 1,12 & 1,24 & 1,32 & 1,41 \\
\hline $\mathbf{n}$ & $\mathbf{9}$ & $\mathbf{1 0}$ & $\mathbf{1 1}$ & $\mathbf{1 2}$ & $\mathbf{1 3}$ & $\mathbf{1 4}$ & $\mathbf{1 5}$ & \\
\hline $\mathbf{R I}$ & 1,45 & 1,49 & 1,51 & 1,48 & 1,56 & 1,57 & 1,59 \\
\hline
\end{tabular}

Dalam hasil penelitian memeriksa konsistensi hierarki, setelah dilakukan perhitungan untuk mencari nilai dari Consistency Ratio (CR) kemudian dilakukan analisis, apabila CR dihasilkan $\leq 0,1$ maka penilaian yang dilakukan konsisten. Namun apabila $\mathrm{CR} \geq 0,1$ maka penilaian yang dilakukan belum konsisten serta perlu diulangi.

\section{Metode Penelitian}

1. Jenis Penelitian

Penelitian ini menggunakan pendekatan kuantitatif yaitu penelitian yang menyelesaikan masalah secara nyata yang menggunakan alat pengumpulan data yang menghasilkan data numerik sistematis, spesifik, dan terstruktur. Hal tersebut dikarenakan untuk mencari bobot prioritas terbaik penerimaan beasiswa Bidikmisi dengan bantuan kuesioner beserta metode yang digunakan sesuai tahapan.

\section{Waktu dan Tempat Penelitian}

Penelitian ini dilakukan pada Februari 2020-Maret 2020 di UIN Sunan Ampel Surabaya, Jl. A. Yani.

\section{Target/Subjek Penelitian/Populasi dan Sampel}

Subjek dalam penelitian ini adalah mahasiswa Sains dan Teknologi tahun 2019. Objek dalam penelitian ini adalah pengambilan keputusan penerimaan beasiswa Bidikmisi dengan menggunakan Analytycal Hierarchy Process (AHP).

\section{Prosedur}

Prosedur digambarkan lebih jelas pada Gambar 2. 


\section{Data, Intrumen, dan Teknik Pengumpulan Data}

Data yang diperoleh melalui wawancara dan penyebaran angket dengan cara memberikan tanda checklist $(\sqrt{ }$ ) pada kolom yang tersedia untuk setiap kriteria maupun sub kriteria. Angket tersebut untuk menentukan bobot setiap kriteria dan sub kriteria yang berkaitan dengan tingkat perbandingan kepentingan dan diberikan kepada validator yaitu pihak yang memiliki pengetahuan dan pengalaman dalam menilai beasiswa Bidikmisi.

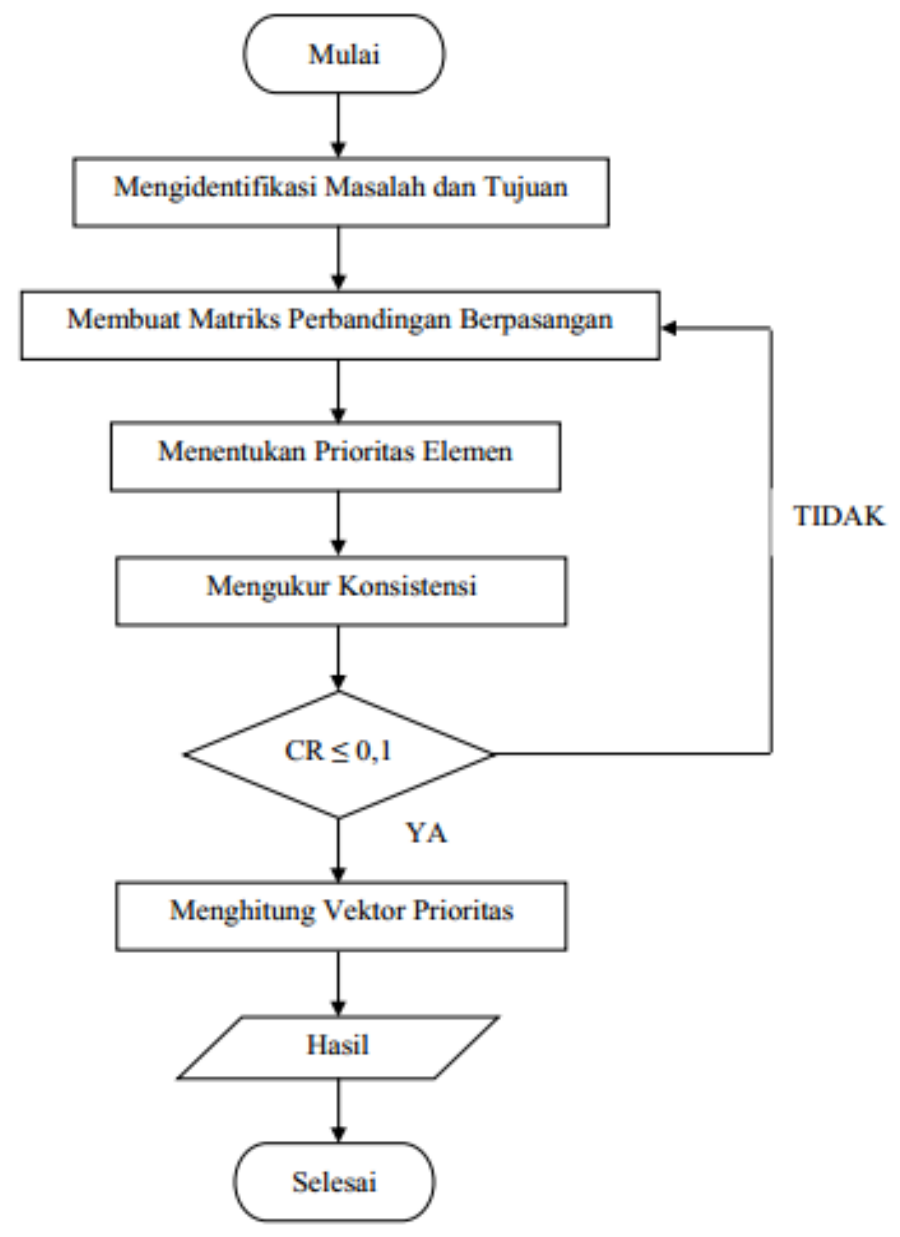

\section{Gambar 2. Prosedur Penelitian Pengambilan Keputusan Penerimaan Beasiswa Bidikmisi Di UINSA dengan Menggunakan Analytical Hierarchy Process (AHP).}

\section{Teknik Analisis Data}

Dilakukan validasi oleh tiga responden yang berisi tentang tingkat kepentingan skala 1-9 antar kriteria maupun sub kriteria. Angket yang didapatkan kemudian dianalisis dengan perbandingan berpasangan untuk menentukan vektor eigen dan nilai eigen.

\section{Hasil Penelitian dan Pembahasan}

\section{Hasil}

Pengambilan keputusan menggunakan Analytical Hierarchy Process (AHP) dengan menentukan kriteria serta sub kriteria. Berdasarkan kriteria serta sub kriteria yang diperoleh dari responden kemudian disusun menjadi suatu hirarki, yang dipaparkan pada Gambar 3. Kemudian melakukan pembobotan untuk matriks perbandingan berpasangan pada tingkat semua kriteria, sebagaimana yang tercantum pada Tabel 4. Dari Tabel 4 tersebut menyatakan bahwa bobot prioritas dari kriteria yang memiliki prioritas tertinggi adalah ekonomi sebesar 0,4389 atau $43,89 \%$, selanjutnya bobot prioritas dari kriteria rumah tinggal keluarga sebesar 0,2743 atau $27,43 \%$, lalu bobot prioritas dari kriteria pendidikan sebesar 0,1854 atau 18,54\%, berikutnya bobot prioritas dari kriteria pekerjaan sebesar 0,1014 atau 10,14\%. 


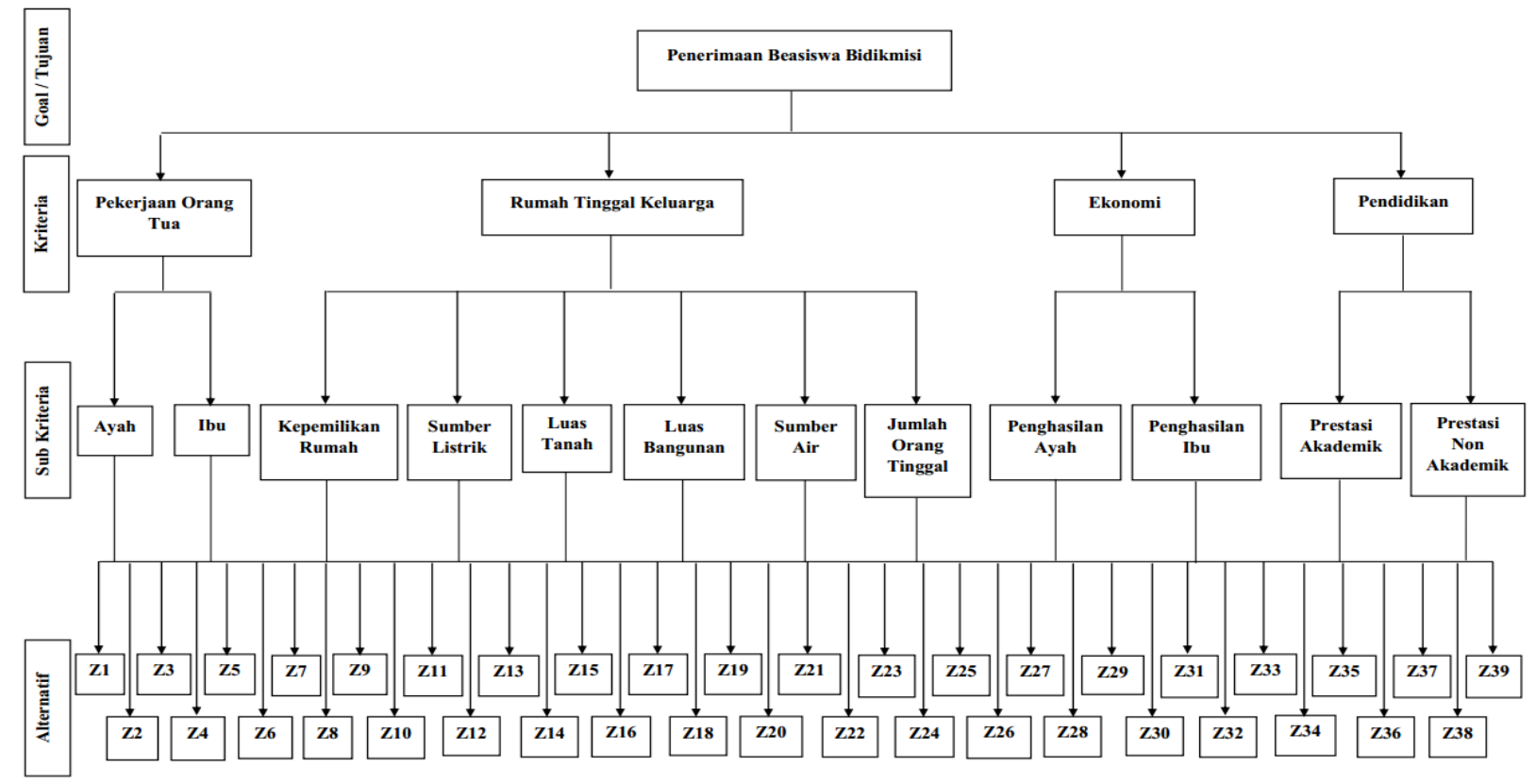

Gambar 3. Struktur Hierarki Penentuan Beasiswa Bidikmisi

Tabel 4. Pembobotan untuk Semua Kriteria

\begin{tabular}{lcccc}
\hline & $\begin{array}{c}\text { Pekerjaan } \\
\text { Ortu }\end{array}$ & $\begin{array}{c}\text { Rumah tinggal } \\
\text { keluarga }\end{array}$ & Ekonomi & Pendidikan \\
\hline $\begin{array}{l}\text { Pekerjaan Ortu } \\
\text { Rumah tinggal }\end{array}$ & 1 & 0,3684 & 0,2370 & 0,5507 \\
keluarga & 2,7144 & 1 & 0,5000 & 1,8171 \\
Ekonomi & 4,2172 & 2,0000 & 1 & 1,9574 \\
Pendidikan & 1,8171 & 0,5501 & 0,5107 & 1 \\
\hline
\end{tabular}

$\lambda_{\text {maks }}=4,0323, C I=0,0108$, dan $C R=0,0119$ berikut:

Setelah itu, melakukan pembobotan sub kriteria pada masing-masing kriteria, sebagai a. Pembobotan Sub Kriteria pada Kriteria Pekerjaan Orang Tua.

Tabel 5. Pembobotan untuk Sub Kriteria pada Kriteria Pekerjaan Orang Tua

\begin{tabular}{lcc}
\hline & Pekerjaan Ayah & Pekerjaan Ibu \\
\hline Pekerjaan Ayah & 1 & 2,7589 \\
Pekerjaan Ibu & 0,3625 & 1 \\
\hline
\end{tabular}

Berdasarkan Tabel 5 tersebut menyatakan bahwa bobot prioritas dari sub kriteria yang memiliki prioritas tertinggi adalah pekerjaan ayah sebesar 0,7340 atau 73,40\%, kemudian bobot prioritas dari pekerjaan ibu sebesar 0,2660 atau $26,60 \%$.

b. Pembobotan Sub Kriteria pada Kriteria Rumah Tinggal Keluarga.

Dari Tabel 6 menyatakan bahwa bobot prioritas dari sub kriteria yang memiliki prioritas tertinggi adalah luas bangunan sebesar 0,3686 atau 36,86\%, selanjutnya bobot prioritas dari sub kriteria luas tanah sebesar 0,2588 atau $25,88 \%$, lalu bobot prioritas dari sub kriteria kepemilikan rumah sebesar 0,1597 atau $15,97 \%$, berikutnya bobot prioritas dari sub kriteria jumlah orang tinggal sebesar 0,1020 atau 10,20\%, kemudian bobot prioritas dari sub kriteria sumber air sebesar 0,0663 atau $6,63 \%$, setelah itu bobot prioritas sub kriteria sumber listrik sebesar 0,0446 atau $4,46 \%$. 
Tabel 6. Pembobotan untuk Sub Kriteria pada Kriteria Rumah Tinggal Keluarga

\begin{tabular}{|c|c|c|c|c|c|c|}
\hline & $\begin{array}{c}\text { Kepemilikan } \\
\text { Rumah }\end{array}$ & $\begin{array}{c}\text { Sumber } \\
\text { Listrik }\end{array}$ & $\begin{array}{c}\text { Luas } \\
\text { Tanah }\end{array}$ & $\begin{array}{c}\text { Luas } \\
\text { Bangunan }\end{array}$ & $\begin{array}{c}\text { Sumber } \\
\text { Air }\end{array}$ & $\begin{array}{c}\text { Jumlah } \\
\text { Orang } \\
\text { Tinggal }\end{array}$ \\
\hline $\begin{array}{l}\text { Kepemilikan } \\
\text { Rumah }\end{array}$ & 1 & 3,7798 & 0,5000 & 0,3466 & 2,8845 & 2,0000 \\
\hline $\begin{array}{l}\text { Sumber } \\
\text { Listrik }\end{array}$ & 0,2646 & 1 & 0,1883 & 0,1586 & 0,5848 & 0,3813 \\
\hline Luas Tanah & 2,0000 & 5,3133 & 1 & 0,5501 & 3,9149 & 3,1748 \\
\hline $\begin{array}{l}\text { Luas } \\
\text { Bangunan }\end{array}$ & 2,8845 & 6,3164 & 1,8171 & 1 & 4,9324 & 3,6342 \\
\hline $\begin{array}{l}\text { Sumber Air } \\
\text { Jumlah } \\
\text { Orang } \\
\text { Tinggal }\end{array}$ & $\begin{array}{l}0,3466 \\
0,5000\end{array}$ & $\begin{array}{l}1,7100 \\
2,8845\end{array}$ & $\begin{array}{l}0,2554 \\
0,3969\end{array}$ & $\begin{array}{l}0,2029 \\
0,2751\end{array}$ & $\begin{array}{c}1 \\
1,5869\end{array}$ & $\begin{array}{c}0,6298 \\
1\end{array}$ \\
\hline
\end{tabular}

c. Pembobotan Sub Kriteria pada Kriteria Ekonomi.

Tabel 7. Pembobotan untuk Sub Kriteria pada Kriteria Ekonomi

\begin{tabular}{lcc}
\hline & Penghasilan Ayah & Penghasilan Ibu \\
\hline Penghasilan Ayah & 1 & 3,1072 \\
Penghasilan Ibu & 0,3217 & 1 \\
\hline
\end{tabular}

Berdasarkan Tabel 7 menyatakan bahwa: bobot prioritas dari sub kriteria yang memiliki prioritas tertinggi adalah penghasilan ayah sebesar 0,7566 atau $75,66 \%$, kemudian bobot prioritas dari penghasilan ibu sebesar 0,2434 atau 24,34\%

d. Pembobotan Sub Kriteria pada Kriteria Pendidikan.

Tabel 8. Pembobotan untuk Sub Kriteria pada Kriteria Pendidikan

\begin{tabular}{lcc} 
& Prestasi Akademik & Prestasi Non Akademik \\
\hline Prestasi Akademik & 1 & 2,8845 \\
Prestasi Non Akademik & 0,3536 & 1 \\
\hline
\end{tabular}

Dari Tabel 8 perhitungan tersebut menyatakan bahwa: bobot prioritas dari sub kriteria yang memiliki prioritas tertinggi adalah prestasi akademik sebesar 0,7407 atau 74,07\%, kemudian bobot prioritas dari prestasi non akademik sebesar 0,2593 atau $25,93 \%$.

Selanjutnya tahapan akhir dengan melakukan prioritas global dengan cara mengalikan faktor evaluasi masing-masing alternatif dengan faktor bobot diperoleh sebagaimana Tabel 9. Dari hasil Tabel 9, diketahui bahwa urutan prioritas mahasiwa yang paling tepat mendapatkan beasiswa Bidikmisi sebagai pilihan mulai dari prioritas 1, 2, dan seterusnya, sebagaimana Tabel 10. Dari Tabel 10 diperoleh bahwa mahasiswa yang diprioritaskan untuk memperoleh beasiswa Bidikmisi urutan 1 sampai dengan 12 berturut-turut Z10, Z35, Z23, Z1, Z19, Z21, Z29, Z20, Z7, Z32, Z2, dan Z5. 


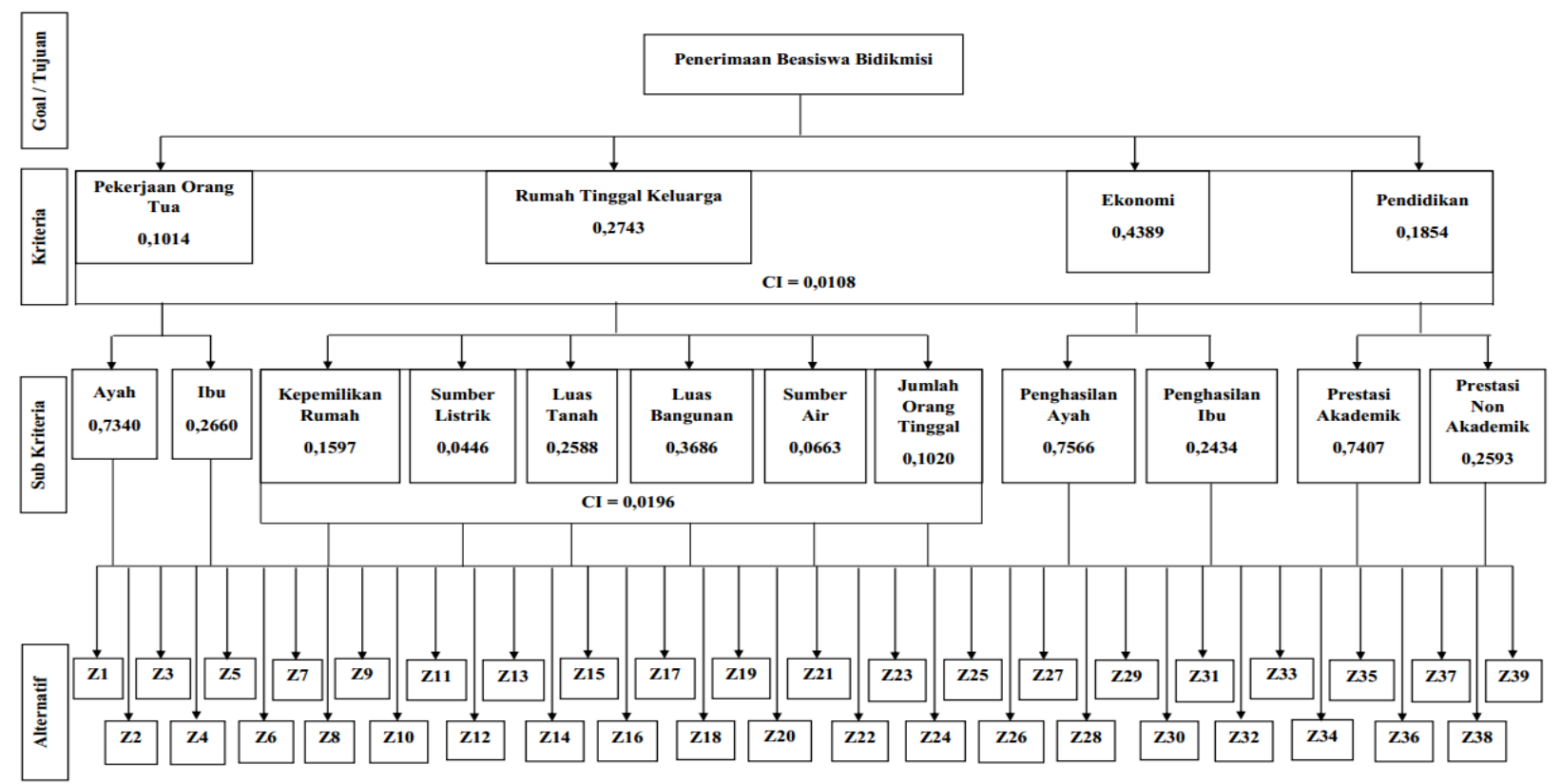

Gambar 4. Hasil Bobot Prioritas dalam Hierarki

Tabel 9. Nilai Prioritas Global

\begin{tabular}{cccccccc}
\hline Z ke- & $\begin{array}{c}\text { Nilai } \\
\text { Prioritas } \\
\text { Global }\end{array}$ & Z ke- & $\begin{array}{c}\text { Nilai } \\
\text { Prioritas } \\
\text { Global }\end{array}$ & Z ke- & $\begin{array}{c}\text { Nilai } \\
\text { Prioritas } \\
\text { Global }\end{array}$ & Z ke- & $\begin{array}{c}\text { Nilai } \\
\text { Prioritas } \\
\text { Global }\end{array}$ \\
\hline 4 & 0,0261 & 13 & 0,0202 & 22 & 0,0254 & 31 & 0,0219 \\
5 & 0,0268 & 14 & 0,0242 & 23 & 0,0343 & 32 & 0,0270 \\
6 & 0,0267 & 15 & 0,0204 & 24 & 0,0276 & 33 & 0,0235 \\
7 & 0,0284 & 16 & 0,0274 & 25 & 0,0208 & 34 & 0,0266 \\
8 & 0,0194 & 17 & 0,0238 & 26 & 0,0264 & 35 & 0,0350 \\
9 & 0,0263 & 18 & 0,0187 & 27 & 0,0269 & 36 & 0,0233 \\
10 & 0,0356 & 19 & 0,0328 & 28 & 0,0244 & 37 & 0,0225 \\
11 & 0,0210 & 20 & 0,0289 & 29 & 0,0292 & 38 & 0,0157 \\
12 & 0,0240 & 21 & 0,0307 & 30 & 0,0237 & 39 & 0,0226 \\
\hline
\end{tabular}

Tabel 10. Alternatif Beasiswa Bidikmisi berdasarkan dengan Nilai Eigen

\begin{tabular}{cccccc}
\hline $\begin{array}{c}\text { Prioritas } \\
\text { ke- }\end{array}$ & $\begin{array}{c}\text { Kode Nama } \\
\text { Beasiswa }\end{array}$ & Nilai Eigen & $\begin{array}{c}\text { Prioritas } \\
\text { ke- }\end{array}$ & $\begin{array}{c}\text { Kode Nama } \\
\text { Beasiswa }\end{array}$ & Nilai Eigen \\
\hline 1 & Z10 & 0,0356 & 7 & Z29 & 0,0292 \\
2 & Z35 & 0,0350 & 8 & Z20 & 0,0289 \\
3 & Z23 & 0,0343 & 9 & Z7 & 0,0284 \\
4 & Z1 & 0,0339 & 10 & Z32 & 0,0270 \\
5 & Z19 & 0,0328 & 11 & Z2 & 0,0269 \\
6 & Z21 & 0,0307 & 12 & Z5 & 0,0268 \\
\hline
\end{tabular}

\section{Pembahasan}

Dalam menentukan keputusan langkah awal yang dilakukan yaitu dengan menentukan tujuan akhir (goal). Dalam hal ini tujuan akhir adalah menetapkan mahasiswa yang akan mendapatkan beasiswa Bidikmisi. Setelah ditentukan tujuan akhirnya, maka langkah selanjutnya adalah menentukan kriteria serta sub kriteria. Setelah diperoleh kriteria dan subkriteria, maka langkah berikutnya adalah penentuan pembobotan atau preferensi dari setiap kriteria yang ada. 
Kemudian menghitung nilai eigen dan vektor eigen untuk semua kriteria yang dapat dilakukan dengan cara normalisasi matriks. Selanjutnya akan dilakukan pengecekan Weighted Sum Vector dengan mengalikan matriks antara matriks asal dengan vektor eigen yang dinormalkan, perhitungan yang dilakukan untuk semua kriteria, sehingga:

$$
M w=\left(\begin{array}{cccc}
1 & 0,3684 & 0,2370 & 0,5507 \\
2,7144 & 1 & 0,5000 & 1,8171 \\
4,2172 & 2,0000 & 1 & 1,9574 \\
1,8171 & 0,5501 & 0,5107 & 1
\end{array}\right)\left(\begin{array}{l}
0,1014 \\
0,2743 \\
0,4389 \\
0,1854
\end{array}\right)=\left(\begin{array}{l}
0,4086 \\
1,1059 \\
1,7780 \\
0,7447
\end{array}\right)
$$

Setelah itu, hasil tersebut dihitung untuk dibagi dengan bobotnya disebut dengan Consistency Vector (CV), sehingga:

$$
C V=\left(\begin{array}{l}
0,4086 / 0,1014 \\
1,1059 / 0,2743 \\
1,7780 / 0,4389 \\
0,7447 / 0,1854
\end{array}\right)=\left(\begin{array}{l}
4,0308 \\
4,0313 \\
4,0514 \\
4,0157
\end{array}\right)
$$

Kemudian mencari nilai eigen maksimum, caranya dengan menjumlahkan nilai Consistency Vector (CV) dengan membagi banyaknya ordo tersebut, sehingga:

$$
\lambda_{\text {maks }}=\frac{(4,0308+4,0313+4,0514+4,0157)}{4}=\frac{16,1292}{4}=4,0323
$$

Langkah selanjutnya yaitu dengan menguji konsistensi data, dengan matriks yang berordo 4 artinya ada 4 kriteria maka nilai indeks konsisten yang didapatkan adalah:

dengan $\mathrm{n}=4$ dan $\mathrm{RI}=0,90$, diperoleh:

$$
C I=\frac{\lambda_{\text {maks }}-n}{n-1}=\frac{4,0323-4}{4-1}=0,0108
$$

$$
C R=\frac{C I}{R I}=\frac{0,0108}{0,90}=0,0119
$$

Karena nilai dari rasio atau CR yang dihasilkan $\leq 0,1$ maka dinyatakan telah konsisten.

Kemudian melakukan pembobotan sub kriteria pada masing-masing kriteria yang di lakukan dengan cara yang sama oleh pembobotan semua kriteria. Tahapan akhir dari metode Analytical Hierarchy Process (AHP) yaitu sintesis prioritas yang didapatkan melalui nilai bobot setiap sub kriteria yang dijumlahkan. Bobot tersebut terdapat 39 mahasiswa dari fakultas Sains dan Teknologi. Dalam mencari prioritas global untuk masing-masing mahasiswa dengan cara seperti berikut:

$$
\begin{aligned}
\mathrm{Z} 1= & (0,1039 * 0,0106)+(0,0741 * 0,0285)+(0,0893 * 0,0289)+(0,0397 * 0,0256)+(0,0770 * \\
& 0,0638)+(0,0881 * 0,0494)+(0,0458 * 0,0288)+(0,0546 * 0,0191)+(0,1424 * 0,0372) \\
& +(0,0301 * 0,0274)+(0,1554 * 0,0353)+(0,0997 * 0,0390) \\
= & 0,0339 \\
\mathrm{Z} 2= & (0,1039 * 0,0106)+(0,0741 * 0,0285)+(0,0893 * 0,0156)+(0,0397 * 0,0256)+(0,0770 * \\
& 0,0101)+(0,0881 * 0,0297)+(0,0458 * 0,0288)+(0,0546 * 0,0191)+(0,1424 * 0,0372) \\
& +(0,0301 * 0,0274)+(0,1554 * 0,0353)+(0,0997 * 0,0390) \\
= & 0,0269 \\
\mathrm{Z} 3= & (0,1039 * 0,0070)+(0,0741 * 0,0056)+(0,0893 * 0,0156)+(0,0397 * 0,0256)+(0,0770 * \\
& 0,0173)+(0,0881 * 0,0164)+(0,0458 * 0,0288)+(0,0546 * 0,0191)+(0,1424 * 0,0197) \\
& +(0,0301 * 0,0137)+(0,1554 * 0,0353)+(0,0997 * 0,0390) \\
= & 0,0213
\end{aligned}
$$

dan seterusnya dengan cara yang sama didapatkan bobot prioritas global untuk setiap mahasiswa.

Proses penerimaan beasiswa Bidikmisi dilakukan dengan cara pengambilan keputusan menggunakan metode Analytical Hirarchy Process (AHP) berdasarkan nilai eigen. Hasil perhitungan diatas bahwa urutan prioritas pertama dan seterusnya yang paling tepat untuk menerima beasiswa Bidikmisi adalah mahasiswa dengan kode Z10, Z35, Z23, Z1, Z19, Z21, Z29, Z20, Z7, Z32, Z2, dan Z5. 


\section{E. Simpulan}

Kriteria yang digunakan dalam beasiswa Bidikmisi terdapat 4 (empat), yaitu pekerjaan orang tua, rumah tinggal keluarga, ekonomi, dan pendidikan. Kriteria yang memiliki prioritas tertinggi adalah ekonomi sebesar $43,89 \%$, selanjutnya bobot prioritas dari kriteria rumah tinggal keluarga sebesar 27,43\%, lalu bobot prioritas dari kriteria pendidikan sebesar 18,54\%, berikutnya bobot prioritas dari kriteria pekerjaan sebesar 10,14\%. Urutan prioritas penerima beasiswa Bidikmisi adalah kode Z10 dengan bobot 3,56\%, kode Z35 dengan bobot 3,50\%, kode Z23 dengan bobot 3,43\%, kode Z1 dengan bobot 3,39\%, kode Z19 dengan bobot 3,28\%, kode Z21 dengan bobot 3,07\%, kode Z29 dengan bobot 2,92\%, kode Z20 dengan bobot 2,89\%, kode Z7 dengan bobot 2,84\%, kode Z32 dengan bobot 2,70\%, kode Z2 dengan bobot 2,69\%, dan kode Z5 dengan bobot $2,68 \%$.

\section{DAFTAR PUSTAKA}

Astuti, Y., Suyanto, M., \& Kusrini. (2011). Sistem Pendukung Keputusan Untuk Pemilihan Perguruan Tinggi Komputer Swasta. Jurnal DASI, 12(1), 56-62.

Darmanto, E., Latifah, N., \& Susanti, N. (2014). Penerapan Metode AHP (Analytic Hierarchy Process) Untuk Menentukan Kualitas Gula Tumbu. Jurnal SIMETRIS, 5(1), 75-82.

Hafiyusholeh, M., \& Asyhar, A. H. (2016). Vektor Prioritas Dalam Analytical Hierarchy Process (AHP) Dengan Metode Nilai Eigen. Jurnal Matematika (MANTIK), 1(2), 44-49.

Hafiyusholeh, M., Ashar, A. H., \& Komaria, R. (2015). Aplikasi Metode Nilai Eigen Dalam Analytical Hierarchy Process Untuk Memilih Tempat Kerja. Jurnal Matematika (MANTIK), 6-16.

Ishak, R. (2016). Sistem Pendukung Keputusan Penelitian Penyuluh Lapangan Keluarga Berencana Teladan dengan Metode Weighted Product. Jurnal Ilmiah ILKOM, 8(3), 160166.

Kirom, D. N., Kadier, R. E., \& Bilfaqih, Y. (2012). Sistem Informasi Manajemen Beasiswa ITS Berbasis Sistem Pendukung Keputusan Menggunakan Metode Analytical Hierarchy Process. Jurnal Teknik ITS, 1(1), 154-159.

Ludfiandini, K., \& Nugroho, S. W. (2015). Analisis dan Penilaian Kinerja Karyawan pada Operator Dump Truck Perusahaan Pertambangan Menggunakan Metode AHP dan Rating Scale (Studi Kasus Pada PT. Pama Indo Mining). Industrial Engineering Online Journal, 4(1).

Magdalena, H. (2012). Sistem Pendukung Keputusan untuk Menentukan Mahasiswa Lulusan Terbaik Perguruan Tinggi (Studi Kasus: STMK ATMA LUHUR PANGKALPINANG) . Semianar Nasional Teknologi Informasi dan Komunikasi 2012 (SENTIKA 2012), 49-56.

Putra, A., \& Hardiyanti, D. Y. (2011). Penentuan Penerimaan Beasiswa dengan Menggunakan Fuzzy Multiple Atribute Decission Making. Jurnal Sistem Informasi (JSI), 3(1), 286-293.

Rizal. (2013). Sistem Pendukung Keputusan Seleksi Calon Penerima Beasiswa pada Universitas Malikussaleh. TECHSI-Jurnal Penelitian Teknik Informatika Universitas Malikussaleh, 5(1), 113-124.

Saaty, T. L. (2002). Decision- making with the AHP: Why is principal eigenvector necessary. EJOR 145.

Saaty, T. L. (2005). Theory and Applications of the Analytic Network Process: Decision Making With Benefits, Opportunities, Costs, and Risks. University of Pittburgh.

Saefudin, \& Wahyuningsih, S. (2014). Sistem Pendukung Keputusan Untuk Penilaian Kerja Pegawai Menggunakan Metode Analytical Hierarchy Process (AHP) Pada RSUD Serang. Jurnal Sistem Informasi, 1(1), 33-37.

Setiawan, F., Indriani, \& Muliadi. (2015). Implementasi Metode ELECTRE pada Sistem Pendukung Keputusan SNMPTN Jalur Undangan Kumpulan. Jurnal Ilmu Komputer (KLIK), 2(2), 88-101. 
Takriyuddin, H., Mukmin, Z., \& Yunus, M. (2016). Pengaruh Beasiswa Bidikmisi Terhadap Prestasi Belajar Mahasiswa Program Studi Pendidikan Pancasila Dan Kewarganegaraan Fakultas Keguruan Dan Ilmu Pendidikan Universitas Syiah Kuala. Jurnal Ilmiah Mahasiswa Pendidikan Kewarganegaraan Unsyiah, 1(1), 49-60. 